характеристики) : практ. порадник / О.О. Дудоров; МВС України, Луган. держ. ун-т внутр. справ ім. Е.О. Дідоренка. Сєвєродонецьк : РВВ ЛДУВС ім. Е.О. Дідоренка, 2018. 92 с.

5. Кримінальне право (Особлива частина): підручник / за ред. О.О. Дудорова, Є.О. Письменського. Т.1. Луганськ: видавництво «Еталон-2». 2012. 780 с.

6. Про судову практику у справах про злочини проти статевої свободи та статевої недоторканості особи : Постанова Пленуму Верховного Суду України від 30.05.2008 № 5 // БД «Законодавство України» / BP України. URL: https://zakon.rada.gov.ua/laws/show/ v0005700-08\#Text (дата звернення: 18.04.2021р.).

7. Дудоров О.О., Хавронюк М.I. Відповідальність за домашнє насильство і насильство за ознакою статі (науково-практичний коментар новел Кримінального кодексу України) : за ред. М. І. Хавронюка. К.: Baiтe, 2019. 288 c.

DOI https://doi.org/10.30525/978-9934-26-074-2-54

\title{
ДО ПИТАННЯ ПРО СТРУКТУРУ, КОЕФІЦЕНТ ЗЛОЧИННОЇ ІНТЕНСИВНОСТІ, ХАРАКТЕР ТА ГЕОГРАФІЮ КРИМННАЛЬНИХ ПРАВОПОРУШЕНЬ ПРОТИ БЕЗПЕКИ РУХУ ТА ЕКСПЛУАТАЦІї ТРАНСПОРТУ В УКРАЇНІ
}

\author{
Новіков О. В. \\ кандидат юридичних наук,
}

асистент кафедри кримінології та кримінально-виконавчого права Національного юридичного університету імені Ярослава Мудрого, старший науковий співробітник відділу кримінологічних досліджень

Науково-дослідного інституту вивчення проблем злочинності імені академіка В. В. Сташиса Національної академії правових наук України м. Харків, Україна

Важливим етапом кримінологічного дослідження будь-якого різновиду злочинності $\epsilon$ аналіз іiі показників. Показники злочинності підлягають вимірюванню для отримання уявлення про іiі розміри, міру змінюваності, ймовірність та величину майбутнього прояву, а також для 
розроблення відповідно до цього предметних заходів щодо запобігання та протидії злочинним проявам [1, с. 156].

Проаналізуємо деякі 3 основних показників кримінальних правопорушень проти безпеки руху та експлуатації транспорту в Україні за 2013-2020 pр., а саме: структуру, коефіцієнт злочинної інтенсивності, характер та географію. Почнемо з аналізу структури цих кримінальних правопорушень.

Під структурою злочинності розуміють розподіл та співвідношення (у відсотках) окремих одиниць сукупності до їх загальної кількості (генеральної сукупності) [2, с. 71]. У процесі вивчення структури злочинності й аналізу окремих їі різновидів вираховується питома вага останніх - або їх частка - в загальній злочинності. У свою чергу, питома вага кількості окремих злочинів може вираховуватися також від загальної кількості злочинів відповідного різновиду [3, с. 104-105]. Отже, спочатку встановимо питому вагу кримінальних правопорушень проти безпеки руху та експлуатації транспорту у структурі злочинності в Україні за 2013-2020 pp.

Питома вага кримінальних правопорушень проти безпеки руху та експлуатації транспорту у структурі злочинності в Україні за 2013-2020 рр.

\begin{tabular}{|c|c|c|c|}
\hline Роки & $\begin{array}{c}\text { Усього } \\
\text { облікованих } \\
\text { кримінальних } \\
\text { правопорушень }\end{array}$ & $\begin{array}{c}\text { Кількість облікованих } \\
\text { примінальних } \\
\text { правопорушень проти } \\
\text { безпеки руху та } \\
\text { експлуатації } \\
\text { транспорту }\end{array}$ & $\begin{array}{c}\text { Питома } \\
\text { вага, \% }\end{array}$ \\
\hline 2013 & 563560 & 19521 & 3,46 \\
\hline 2014 & 529139 & 24497 & 4,63 \\
\hline 2015 & 565182 & 23837 & 4,22 \\
\hline 2016 & 592604 & 26010 & 4,39 \\
\hline 2017 & 523911 & 21904 & 4,18 \\
\hline 2018 & 487133 & 17375 & 3,57 \\
\hline 2019 & 444130 & 17210 & 3,87 \\
\hline 2020 & 360622 & 15795 & 3,94 \\
\hline Усього & 4066281 & 166149 & 4,03 \\
\hline
\end{tabular}

Як можна побачити, в середньому за досліджуваний період кримінальні правопорушення проти безпеки руху та експлуатації транспорту складали 4,03\% у структурі злочинності в Україні. А станом на 2020 р. 
зазначена група кримінальних правопорушень займає 6 місце за поширенням у державі після кримінальних правопорушень проти власності (52,76\%), кримінальних правопорушень проти життя та здоров'я особи (10,35\%), кримінальних правопорушень у сфері обігу наркотичних засобів, психотропних речовин, їх аналогів або прекурсорів та інших кримінальних правопорушень проти здоров'я населення (7,8\%), кримінальних правопорушень проти авторитету органів державної влади, органів місцевого самоврядування, об'єднань громадян та кримінальних правопорушень проти журналістів (5,71\%), кримінальних правопорушень у сфері службової діяльності та професійної діяльності, пов'язаної з наданням публічних послуг (5,27\%) [4, с. 121].

Внутрішня структура кримінальних правопорушень проти безпеки руху та експлуатації транспорту за 2020 р. зображена на діаграмі нижче.

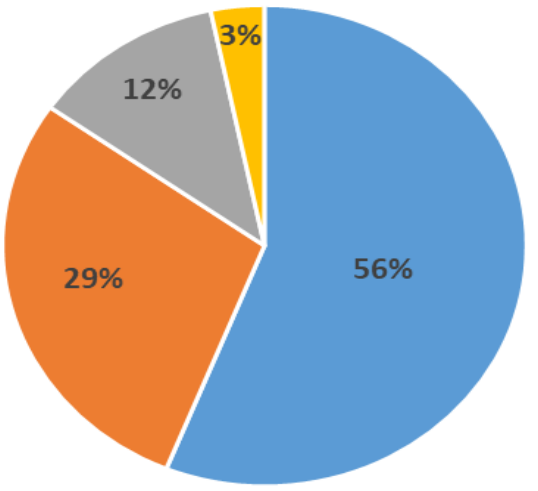

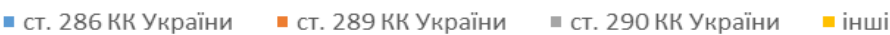

\section{Рис. 1. Структура кримінальних правопорушень проти безпеки руху} та експлуатації транспорту в Україні за 2020 р.

Як можна побачити, найбільш поширеними серед цих правопорушень є: порушення правил безпеки дорожнього руху або експлуатації транспорту особами, які керують транспортними засобами (ст. 286 КК України), незаконне заволодіння транспортним засобом (ст. 289 КК України) та знищення, підробка або заміна номерів вузлів та агрегатів транспортного засобу (ст. 290 КК України).

Тепер проаналізуємо коефіцієнт злочинної інтенсивності кримінальних правопорушень проти безпеки руху та експлуатації транспорту за 2013-2020 pp.

Під коефіцієнтом злочинної інтенсивності розуміють відношення кількості зареєстрованих кримінальних правопорушень на певній території за визначений період часу до всього населення або певної 
кількості населення в розрахунку на заздалегідь обумовлену одиницю аналізу, як правило, 10 і 100 тис. населення [2, с. 70].

Коефіцієнт злочинної інтенсивності кримінальних правопорушень проти безпеки руху та експлуатації транспорту в Україні в розрахунку на 100 тис. населення за 2013-2020 pp.

\begin{tabular}{|c|c|c|c|}
\hline Роки & $\begin{array}{c}\text { Чисельність } \\
\text { населення } \\
\text { (тис. осіб) } \\
\text { станом на } \\
\text { 1 січня } \\
\text { поточного } \\
\text { року }\end{array}$ & $\begin{array}{c}\text { Кількість облікованих } \\
\text { кримінальних } \\
\text { правопорушень проти } \\
\text { безпеки руху та } \\
\text { експлуатації транспорту }\end{array}$ & $\begin{array}{c}\text { Коефіцієнт } \\
\text { злочинної } \\
\text { інтенсивності на } \\
100 \text { тис. населення } \\
\text { України }\end{array}$ \\
\hline 2013 & 45553,0 & 19521 & 42,85 \\
\hline 2014 & 45426,2 & 24497 & 53,93 \\
\hline 2015 & 42929,3 & 23837 & 55,53 \\
\hline 2016 & 42760,5 & 26010 & 60,83 \\
\hline 2017 & 42584,5 & 21904 & 51,44 \\
\hline 2018 & 42386,4 & 17375 & 40,99 \\
\hline 2019 & 42153,2 & 17210 & 40,83 \\
\hline 2020 & 41902,4 & 15795 & 37,69 \\
\hline
\end{tabular}

Як бачимо, найбільше значення коефіцієнта злочинної інтенсивності аналізованих кримінальних правопорушень припадає на 2016 р. (близько 61 кримінальне правопорушення на 100 тис. населення), а найменше - на 2020 р. (близько 38 кримінальних правопорушень на 100 тис. населення).

Характер злочинності - це якісний показник, що визначає питому вагу тяжких та особливо тяжких кримінальних правопорушень у їх загальній кількості [2, с. 71]. Так, серед 15795 кримінальних правопорушень проти безпеки руху та експлуатації транспорту за 2020 р. було обліковано: 746 особливо тяжких злочинів, 4940 тяжких злочинів, 5407 - нетяжких злочинів та 1884 кримінальних проступків. Отже, характер досліджуваних кримінальних правопорушень дорівнює 36\%, тобто трохи більш ніж кожне третє кримінальне правопорушення проти безпеки руху та експлуатації транспорту є тяжким чи особливо тяжким. Майже $70 \%$ серед цих кримінальних правопорушень складають злочини та 30\% - кримінальні проступки.

Географія злочинності - це показник, за яким досліджується територіальне розповсюдження злочинності за певний період, а також регіональні особливості кількісних та якісних показників злочинності [2, с. 73]. 
Що стосується географії кримінальних правопорушень проти безпеки руху та експлуатації транспорту, то найбільша кількість цих кримінальних правопорушень виявляється у - м. Києві, Дніпропетровській, Одеській, Харківській, Київській та Львівській областях, а найменше у - Луганській, Чернігівській, Тернопільській, Кіровоградській та Хмельницькій областях.

\section{Література:}

1. Закалюк А. П. Курс сучасної української кримінології: теорія i практика. У 3 кн. Кн. 1: Теоретичні засади та історія української кримінологічної науки. Київ: Видавничий дім «Ін Юре», 2007. 424 с.

2. Кримінологія : підручник / [Б. М. Головкін, В. В. Голіна, О. В. Лисодєд та ін.]; за заг. ред. Б. М. Головкіна. Харків : Право, 2020. 384 c.

3. Криминология: учебник для вузов / Под общей ред. д. ю. н., проф. А. И. Долговой. 3-е изд., перераб. и доп. М.: Норма, 2007. 912 с.

4. Новіков О. В. Рівень, структура, динаміка кримінальних правопорушень проти безпеки руху та експлуатації транспорту в Україні. Злочинність $i$ протидія п̈й в умовах сингулярності: тендениії та інновачіï: зб. тез доп. наук.-практ. конф., присвяч. пам'яті члена Правління Кримінологічної асоціації України, професора Тетяни Андріївни Денисової (м. Харків, 16 квіт. 2021 р.) / МВС України, Харків. нац. ун-т внутр. справ, Кримінол. асоц. України. Харків : ХНУВС, 2021. 464 c. C. $120-123$.

DOI https://doi.org/10.30525/978-9934-26-074-2-55

\section{ЗАГАЛЬНИЙ ОГЛЯД ПІДСТАВ ДЕКРИМІНАЛІЗАЦІї}

\section{Пустова Н. О.}

аспірантка кафедри кримінального права і кримінології факультету № 1

Інституту з підготовки фахівців для підрозділів Національної поліиії Львівського державного університету внутрішніх справ м. Львів, Украӥна

Підстава - це основний чинник декриміналізації діянь, оскільки саме вона характеризує необхідність зміни кримінального законодавства. У філософії підстава визначається як необхідна умова виникнення буття, пізнання, думки, діяльності тощо [1, с. 614]. Підстава відрізняється від інших умов своєю необхідністю. Отже, підстава - це необхідна умова, 